\title{
PERENCANAAN SISTEM INFORMASI AKADEMIK MENGGUNAKAN ZACHMAN FRAMEWORK
}

\author{
Rosmiati \\ Sistem Informasi dan STMIK Palangkaraya \\ Jl. G.Obos No.114 Palangka Raya \\ Email: fayadhah@gmail.com
}

\section{ABSTRACT}

Academic information system planning can provide a guide in the design of academic information systems aligned with the business processes of an organization. SMK Isen Mulang yet have an Academic Information System planning are aligned with business processes. It required an academic information system planning can provide clear guidelines in the use of information technology for academic affairs at SMK Isen Mulang.

Analysis of the needs required in the planning of Academic Information System using Zachman Framework approach. Each cell of the matrix Zachman discussed in depth to analyze the needs of Academic Information Systems of SMK Isen Mulang Palangkaraya. For the modeling used E-R diagrams, UML diagrams, and for examples of interface design using GUI Design Studio.

The result of this research study is a vocational blueprint by using Zachman Academic Information Framework. Zachman Framework Approach to describe clearly and in detail the parts of planning academic Academic Information Systems in a simple model. This plan resulted in a blueprint that can be used as a reference are structured in making academic information system program code and test development in SMK Isen Mulang Palangkaraya.

Keywords: Academic Information Systems, Zachman Framework, Chart E-R

\section{PENDAHULUAN}

\section{Latar Belakang}

Sekedar menggunakan teknologi dalam pengolahan informasi sudah menjadi suatu standar umum organisasiorganisasi masa kini. Kecepatan dan keakuratan pengolahan informasi adalah tuntutan perubahan zaman terhadap keberlangsungan organisasi modern saat ini. Akibatnya, penggunaan teknologi sistem informasi suatu organisasi bukan lagi menjadi suatu tambahan nilai (addedvalue) bagi organisasi, tetapi telah menjadi suatu kebutuhan yang harus dipenuhi. Oleh sebab itu, untuk menjadikan teknologi sistem informasi sebagai suatu kekuatan bagi suatu organisasi, maka dibutuhkan suatu 
perencanaan sistem informasi yang baik. Kemampuan institusi dalam menganalisis kebutuhan stakeholder yang selaras dengan sistem informasi akademik merupakan salah satu kunci penting dalam menghadapi persaingan antar Sekolah Menengah Kejuruan dan meningkatkan pelayanan jasa pendidikan institusi.

Hingga saat ini, proses pengolahan nilai siswa adalah pertamatama nilai siswa dituliskan oleh Guru Mata Pelajaran ke selembar formulir secara manual. Kemudian setelah dihitung nilai akhir masing-masing siswa, lembar tersebut diserahkan kepada Wakil Kepala Sekolah bidang kurikulum untuk ditandatangani, kemudian diserahkan kepada Kepala Sekolah untuk ditandatangani. Setelah itu, lembar tersebut baru diserahkan ke bagian Akademik untuk diinputkan nilainya ke file Excel.

Demikian pula pengolahan nilai rapor. Wali kelas menerima hasil print nilai akhir siswa untuk seluruh mata pelajaran, diperiksa, kemudian diinputkan secara manual ke file Excel yang sudah disediakan. Wali kelas juga harus mengecek jumlah kehadiran secara manual (dengan melihat buku absensi siswa), kemudian menginputkannya secara manual ke file Excel yang disediakan. Perencanaan sistem informasi yang tepat menjadi kunci penting bagi sekolah untuk bertahan dalam persaingan antar sekolah swasta yang begitu ketat di Palangka Raya.

Oleh karena itu, dibutuhkan sebuah framework yang mampu mengakomodasi kepentingan semua pihak yang terlibat dan mampu mengidentifikasi setiap aspek yang diperlukan. Salah satu framework yang dapat melihat permasalahan dalam pembangunan sebuah sistem informasi di suatu perusahaan dari berbagai sudut pandang adalah Zachman Framework (Adhinugraha, 2007).

Zachman Frameworkmerupakan salah satu kerangka pemodelan sistem informasi yang dapat mendefinisikan organisasi secara lengkap dengan menggunakan model yang sederhana bagi segala macam subjek.

\section{Rumusan Masalah}

Permasalahan yang dapat penulis rumuskan adalah "Bagaimanakah perencanaan sistem informasi akademik menggunakan Zachman Framework di SMK Isen Mulang?”

\section{Tujuan Penelitian}


Berdasarkan latar belakang dan identifikasi masalah yang telah diuraikan di atas, maka tujuan penelitian ini adalah untuk menghasilkan suatu blueprint perencanaan sistem informasi akademik dengan menggunakan Zachman Framework di SMK.

\section{Tinjauan Pustaka}

Penelitian mengenai Zachman Framework telah dilakukan oleh beberapa peneliti lain. Namun, penelitian pada SMK belum pernah dilakukan. Dalam tinjauan pustaka ini, akan dibahas secara singkat beberapa penelitian terdahulu yang telah dilakukan oleh peneliti-peneliti lain, mengenai pemanfaatan Zachman Framework dalam Sistem Informasi.

Landasan Teori

\section{Sistem Informasi}

Menurut (Valacich, George, \& Hoffer, 2012), sebuah sistemadalah himpunanyang saling terkait dariprosedur bisnis(atau komponen) yang digunakan dalam satuunit bisnis,yang bekerja sama untukbeberapa tujuan.Suatu sistem mempunyai 9 karakteristik. Sembilan karakteristik sistem tersebut adalah components, interellated components, Boundrary, Purpose, Environment, Interfaces, Constraints, Input, dan Output.
Sedangkan, menurut Shelly (Shelly \& Rosenblatt, 2012), sebuah sistemadalah seperangkatkomponen terkaityang menghasilkanhasil tertentu. Dalam sebuah sisteminformasi,data terdiri darifakta-fakta dasaryangmenjadi bahan bakubagi sistem.Informasi adalah data yangtelah berubah menjadioutput yangbernilai bagipengguna. Menurut Shelly, terdapat 5 komponen utama dari suatu sistem informasi, yaitu hardware, software, data, proses, dan manusia.

Hardware terdiri dari semua yang ada di lapisan fisik sistem informasi. Sebagai hardware adalah server, workstation, jaringan, peralatan telekomunikasi, dan infrastruktur berbasis teknologi lainnya. Software adalah program komputer yang mengontrol hardware dan menghasilkan hasil atau informasi yang diinginkan. Software sistem mengatur komponen hardware, yang dapat berupa sebuah workstation tunggal atau suatu jaringan global dengan ribuan client.

Data merupakan materi mentah yang akan diubah oleh sistem informasi menjadi informasi yang berguna. Sistem informasi menyimpan data dalam berbagai lokasi yang disebut tabel. Dengan menghubungkan tabel-tabel, sistem dapat mengambil informasi 
tertentu. Proses menggambarkan tugas dan fungsi bisnis yang dilakukan oleh user, manajer, dan anggota staf TI untuk mencapai hasil tertentu. Proses merupakan hal yang penting bagi suatu sistem informasi karena proses menyatakan operasi bisnis harian yang aktual. Untuk membangun suatu sistem informasi yang sukses, seorang analis harus memahami proses bisnis dan mendokumentasikannya dengan hatihati.

Selanjutnya menurut (Laudon \& Laudon, 2012), Sistem Informasi dapat didefinisikan secara teknis sebagai seperangkat komponen yang saling terkait yang mengumpulkan (atau mengambil), memproses, menyimpan, dan mendistribusikan informasi untuk mendukung pengambilan keputusan dan kontrol dalam sebuah organisasi. Menurut (Laudon \& Laudon, 2012), terdapat tiga aktivitas dalam sistem informasi yang menghasilkan informasi yang diperlukan organisasi dalam membuat keputusan, pengontrolan operasi, analisis masalah, dan membuat produk atau jasa baru. Aktifitas-aktifitas ini adalah input, proses, dan output. Input menangkap dan mengoleksi data mentah dari organisasi atau dari lingkungan luarnya. Proses mengubah input mentah ini ke bentuk yang mempunyai arti. Output mengirimkan informasi yang telah diproses ke orang yang akan menggunakannya atau ke aktivitas yang menggunakannya. Sistem informasi juga memerlukan

feedback,yaituoutput yang dikembalikan kepada anggota yang sesuai dalam organisasi untuk membantu mereka mengevaluasi atau memperbaiki tahapan input.

\section{Perencanaan Sistem Informasi}

Menurut (Smith, van der Poel, \& Ribbers, 2003), strategi informasi didefinisikan sebagai suatu visi, tujuan, panduan, dan rencana implisit atau eksplisit yang kompleks berkaitan dengan persediaan dan permintaan dari informasi formal dalam suatu organisasi. Sedangkan dalam buku yang sama, dikatakan bahwa definisi SISP (Strategic Information Systems Planning) didefinisikan oleh Lederer dan Sethi sebagai proses pengambilan keputusan tentang sasaran organisasi dan mengidentifikasi aplikasi komputer potensial yang seharusnya diimplementasikan.

Menurut Cassidy (2006), perencanaan strategi sistem informasi diperlukan karena proses perencanaan sistem informasi memungkinkan sistem 
informasi membantu perusahaan mencapai tujuan bisnisnya.

\section{Framework (Kerangka Kerja)}

Menurut Zachman (Zachman, 1987), subjek mengenai arsitektur sistem informasi mulai menerima perhatian. Peningkatan cakupan desain dan tingkatan kompleksitas dari implementasi sistem informasi telah memaksa penggunaan suatu konstruksi logis (arsitektur) untuk mendefinisikan dan mengendalikan antar muka dan integrasi dari seluruh komponen sistem. Zachman Framework (Zachman, 1987) terdiri dari matriks berukuran $3 \times 5$, dimana 3 kolom mewakili aspek yang berbeda dan 5 baris mewakili perspektif berbeda.

\section{Analisis}

\section{Analisis Kebutuhan}

Bagian analisis kebutuhan ini terdiri dari dua bagian. Pertama, tinjauan objek penelitian, yaitu penjelasan yang menggambarkan keadaan objek penelitian saat ini. Kedua, metodologi penelitian, yaitu menjelaskan metode penelitian dan teknik pengumpulan data serta pemilihan sampel.

Dalam penelitian ini, data yang hendak diteliti dikumpulkan menggunakan teknik-teknik sebagai berikut:

a. Observasi
Observasi adalah teknik pengumpulan data dengan melakukan pengamatan langsung terhadap subjek (partner penelitian) di mana sehari-hari mereka berada dan biasa melakukan aktivitasnya..

b. Studi Dokumentasi

Selain sumber manusia (human resources) melalui observasi, sumber lainnya sebagai pendukung yaitu dokumen-dokumen tertulis yang resmi ataupun tidak resmi.

\section{Scope Description}

Berikut ini akan dijabarkan mengenai hal-hal apa saja yang terdapat dalam sel-sel baris Scope Description ini untuk kolom Data Description, Process Description, dan Network Description.

\section{Modelof the Business (Owner's View)}

Sudut pandang owner menjelaskan konsep atau rancangan umum dari sistem yang akan dibangun berdasarkan hasil yang didapatkan sebelumnya, yaitu dari baris scope description.

\section{Model of the Information System}

(Designer's View)

Sudut pandang ini menggambarkan desain formal dari sistem yang akan dibangun. Desain ini merupakan jembatan antara pihak 
manajemen pada perspektif planner dan owner dengan pihak yang akan merealisasikan sistem ini pada perspektif builder..

\section{Technology Model (Builder's View)}

Sudut pandang ini menggambarkan keterbatasan teknologi yang dipergunakan dalam membangun sistem informasi. Jadi dalam baris yang merupakan sudut pandang dari sisi Builder ini, akan dijabarkan mengenai perancangan interface (GUI) dari sistem informasi SMK Isen Mulang Palangka Raya.

\section{Detailed Description (Out-of-Context}

View)

Bagian ini berisikan listing program, spesifikasi database, jaringan yang kesemuanya dinyatakan dalam istilahistilah bahasa pemrograman tertentu.

\section{Pembahasan Penelitian}

Berdasarkan data yang telah dikumpulkan dengan menggunakan metode observasi, partisipasi, dan studi dokumentasi, maka selanjutnya dilakukan penelitian dengan menganalisa data berdasarkan Zachman Framework. Pembahasan akan dimulai dari menganalisis setiap isi dari sel pada baris pertama matriks Zachman hingga baris kelima matriks Zachman.

\section{Baris Scope Description}

(BallparkView)

Baris pertama ini berisikan deskripsi lingkupan (scope description) mengenai hal-hal yang akan menjadi batasan pembahasan bagi baris-baris berikutnya dari matriks Zachman. Berikut ini merupakan penjelasan untuk masingmasing kolom pada baris Scope Description.

\section{Kolom Process Description}

Kolom deskripsi proses ini menjelaskan fungsi-fungsi dari masingmasing entitas di bagian akademik SMK Isen Mulang Palangka Raya. Peranan dari masing-masing entitas dalam bagian akademik SMK Isen Mulang Palangka Raya ini diperoleh dari studi terhadap dokumen internal SMK Isen Mulang Palangka Raya. Berikut merupakan peranan masingmasing entitas dalam bagian akademik SMK Isen Mulang Palangka Raya.

\section{Kolom Network Description}

Bagian ini berisikan lokasi masing-masing entitas dalam melakukan peranannya menyukseskan kegiatan akademik di SMK Isen Mulang Palangka Raya.

Baris Model of TheBusiness (Owner's View) 
Dalam bagian ini, akan dijelaskan model bisnis dan proses bisnis menurut sudut pandang dari pemilik (Owner). Sudut pandang owner menjelaskan mengenai konsep atau rancangan umum berdasarkan analisis dari baris scope description.

\section{Kolom Data Description}

Bagian ini berisikan bagaimana hubungan antara entitas dengan menggunakan diagram E-R. Diagram E$\mathrm{R}$ menunjukkan hubungan antar-entitas yang ada di bagian akademik SMK Isen Mulang Palangka Raya.

Diagram Hubungan Entitas atau Entity Relational Diagram merupakan model data berupa notasi grafis dalam pemodelan data konseptual yang menggambarkan hubungan antara penyimpan. Diagram hubungan entitas ditemukan oleh Peter Chen dalam buku Entity Relational Model-Toward a Unified of Data. Chen mencoba merumuskan dasar-dasar model dan setelah itu dikembangkan dan dimodifikasi oleh Chen dan banyak pakar lainnya.

Berikut ini merupakan gambar diagram E-R yang menunjukkan hubungan entitas-entitas yang ada pada bagian akademik SMK Isen Mulang Palangka Raya.

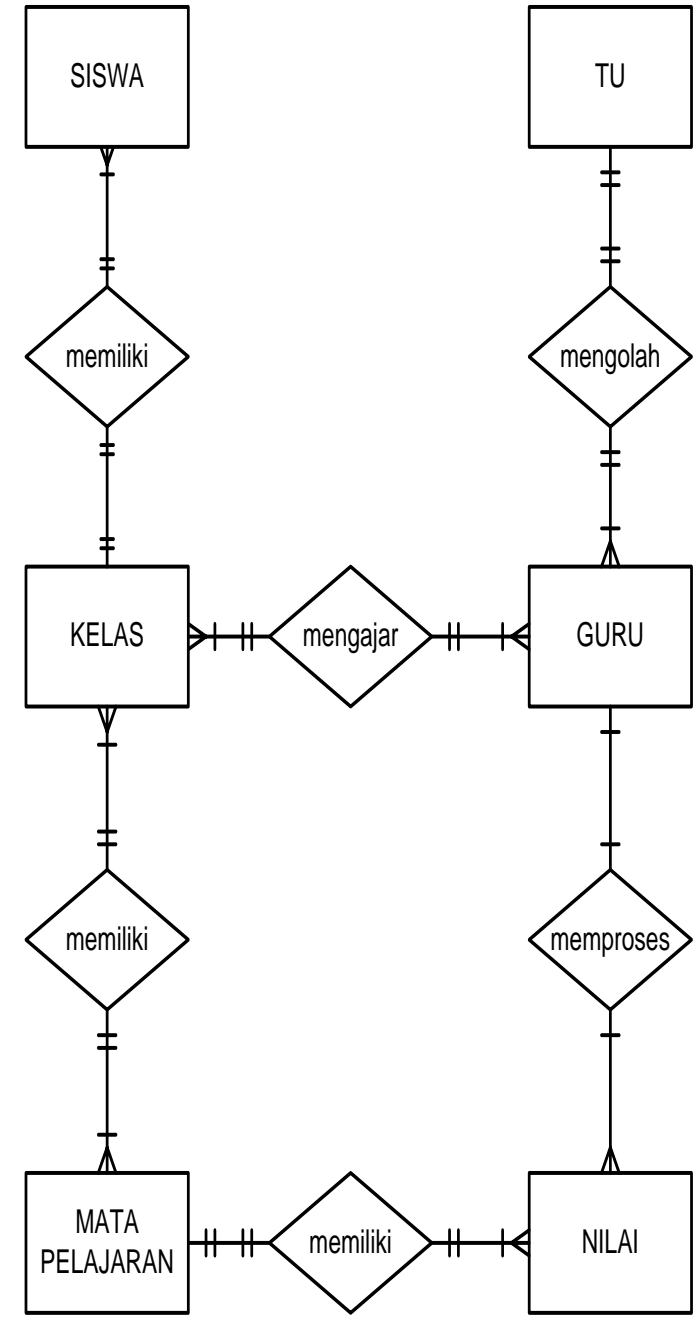

Gambar 1

Diagram E-R Hubungan Entitas-entitas Bagian Akademik

Diagram di atas dapat dijelaskan sebagai berikut. Setiap siswa hanya dapat menempati satu kelas, setiap kelas memiliki satu atau lebih dari satu siswa. Dalam suatu kelas atau tingkatan, terdapat beberapa mata pelajaran.

\section{Kolom Process Description}

Bagian ini menjelaskan mengenai proses yang terjadi di bagian akademik SMK Isen Mulang Palangka 
Raya. Proses yang ada di bagian akademik SMK Isen Mulang Palangka Raya ini akan digambarkan dalam suatu Functional Flow Diagram (FFD).

Berikut ini adalah FFD untuk proses pengolahan nilai untuk guru Mata Pelajaran.

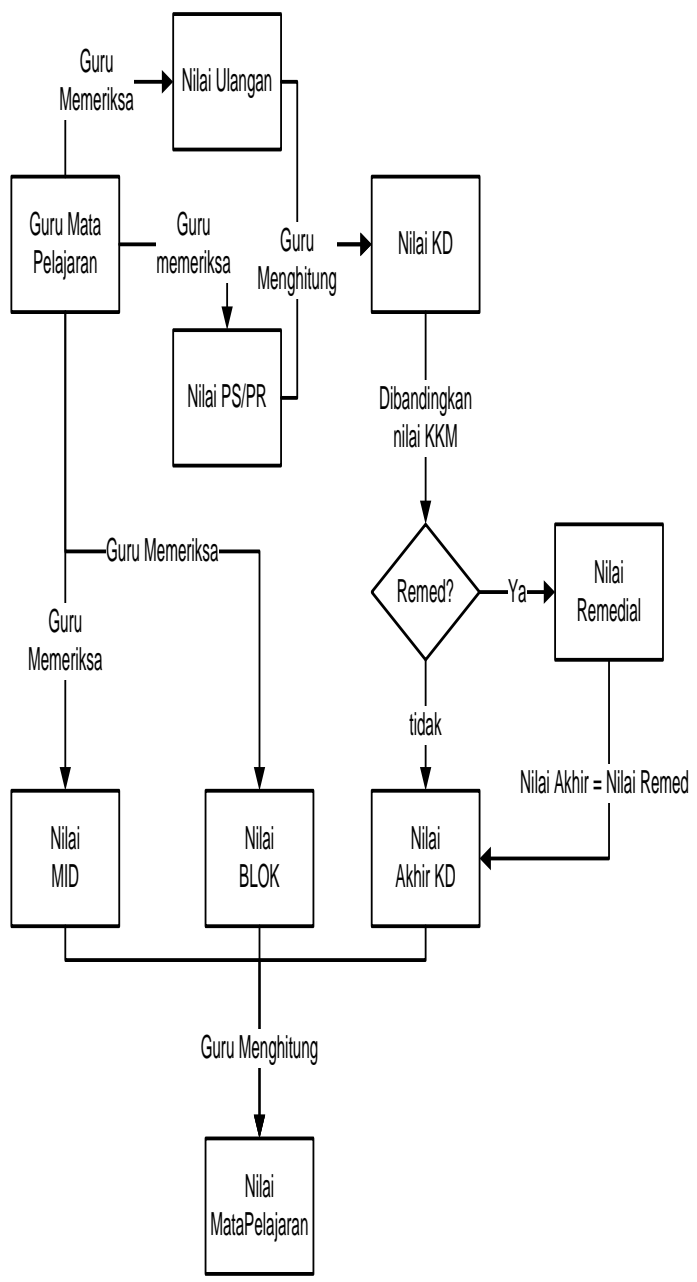

Gambar 2

Function Flow Diagram Guru Mata

Pelajaran

Berikut ini adalah penjelasan diagram di atas. Guru mata pelajaran memberikan tugas berupa pekerjaan sekolah (PS) atau pekerjaan rumah (PR), kemudian mengolah nilainya menjadi nilai $\mathrm{PS} / \mathrm{PR}$.

Berikut ini adalah FFD untuk TU

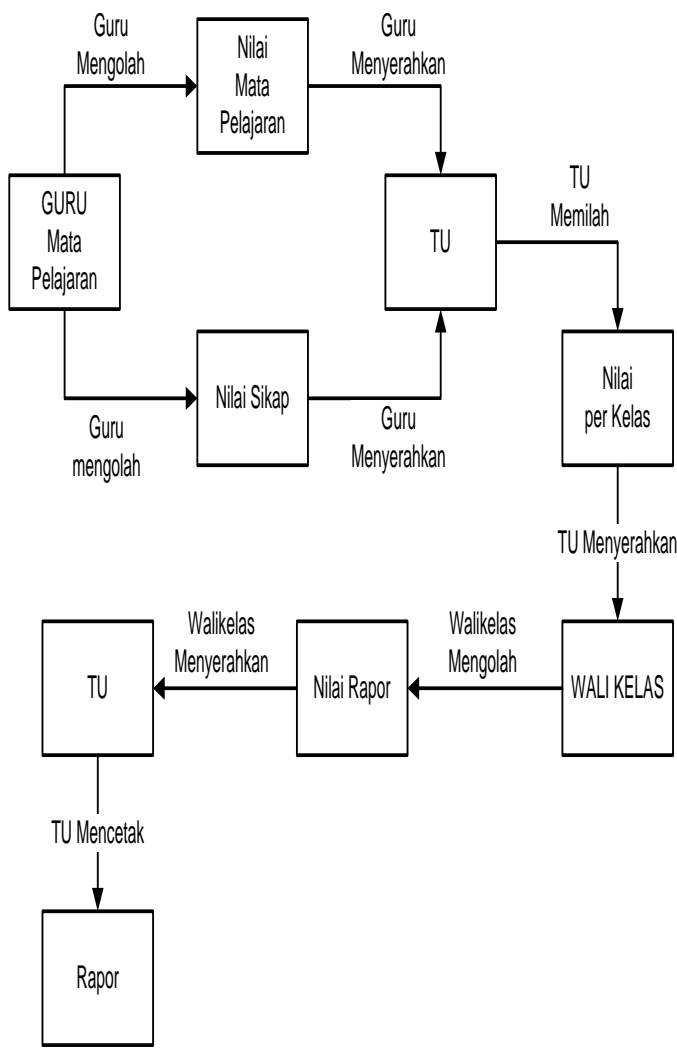

Gambar 3

Function Flow Diagram TU

Penjelasan FFD di atas adalah sebagai berikut. Guru mata pelajaran akan mengumpulkan nilai mata pelajaran yang diasuhnya ke TU.

\section{Kolom Network Description}

Kolom ini berisikan lokasi dan hubungan antar-lokasi di mana proses bisnis dari bagian Akademik SMK Isen Mulang Palangka Raya berlangsung. Lokasi dan hubungannya digambarkan dalam bentuk jaringan sederhana berupa node-node dan garis yang menghubungkan node-node tersebut. Berikut ini merupakan diagramnya. 


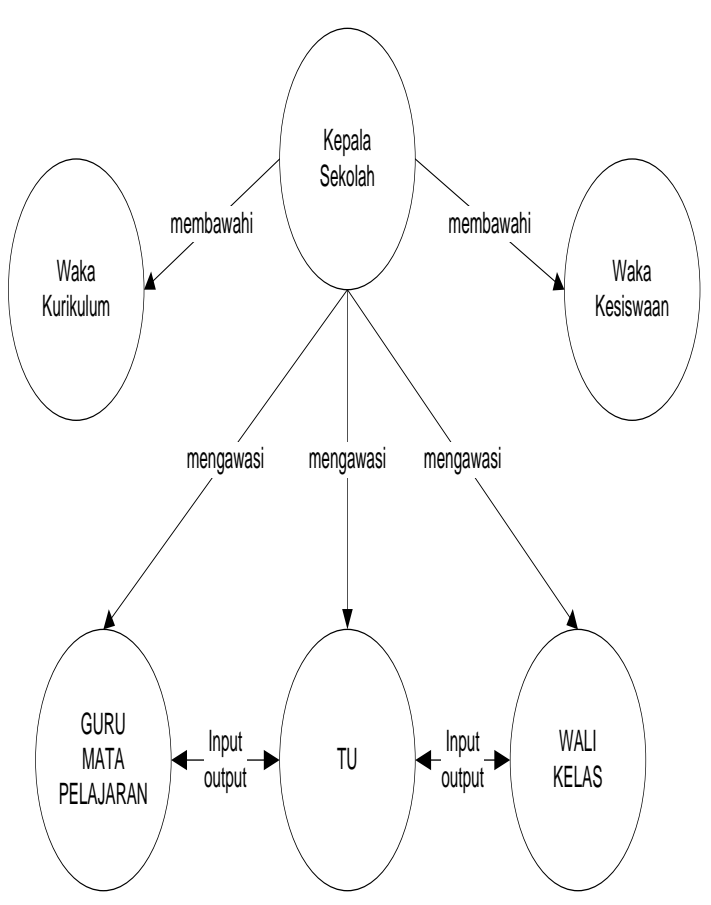

Gambar 4

Topologi jaringan lokasi entitas proses bisnis bagian Akademik

\section{Baris Model of the Information}

\section{System (Designer's View)}

Baris ketiga dari matriks Zachman ini menjelaskan bagaimana model konseptual dari bisnis dilihat dari sudut pandang Designer.

\section{Kolom Data Description}

Dalam hal ini, bentuk pemodelan data yang dipergunakan adalah Entity Relationship Diagram (ER Diagram)

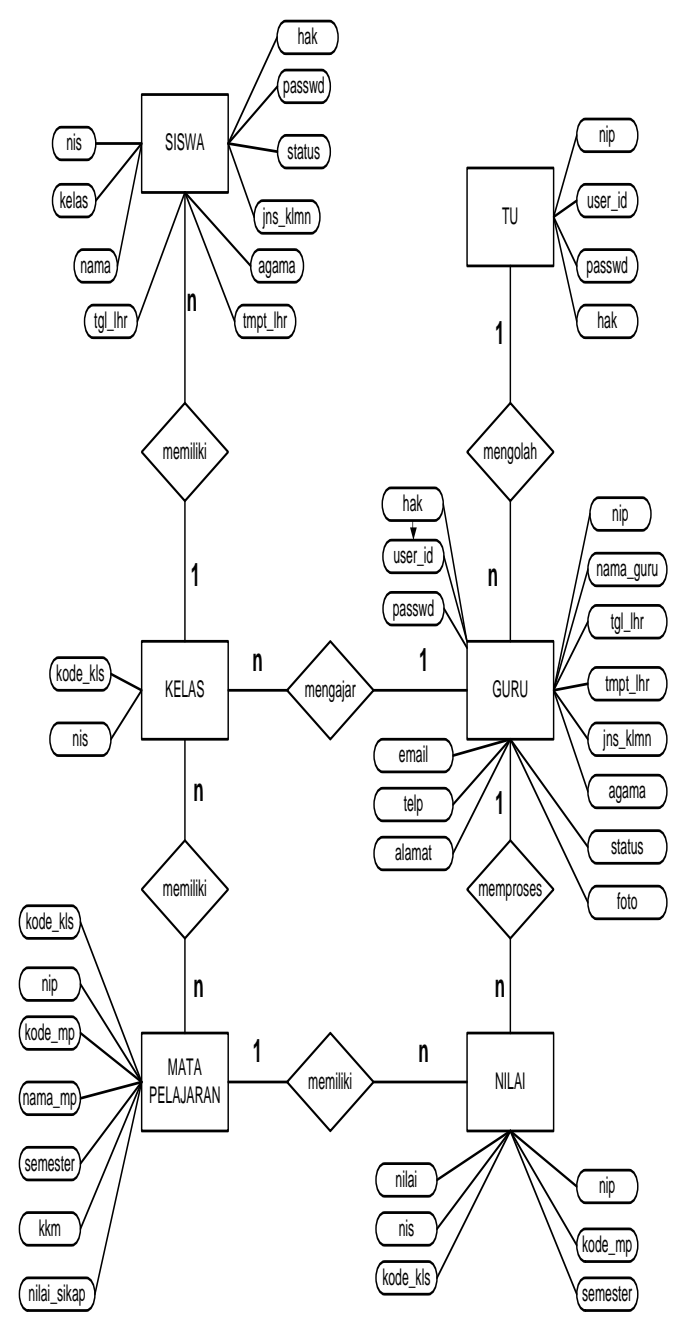

Gambar 5

Diagram E-R Akademik SMK Isen Mulang Palangka Raya dengan attributnya

Pada gambar, terlihat bahwa masingmasing entitas memiliki attribut yang digambarkan dalam bentuk elips. Atribut-atribut ini yang akan digunakan dalam perancangan database.

\section{Kolom Process Description}

Pada bagian ini akan dimodelkan bagaimana proses-proses yang terjadi di bagian Akademik SMK Isen Mulang Palangka Raya setelah 
adanya sistem informasi usulan. Proses tersebut akan dimodelkan dengan menggunakan Use Case Diagram.

Berikut ini adalah gambar Use Case Diagram yang menggambarkan proses yang terjadi di bagian akademik SMK Isen Mulang Palangka Raya.

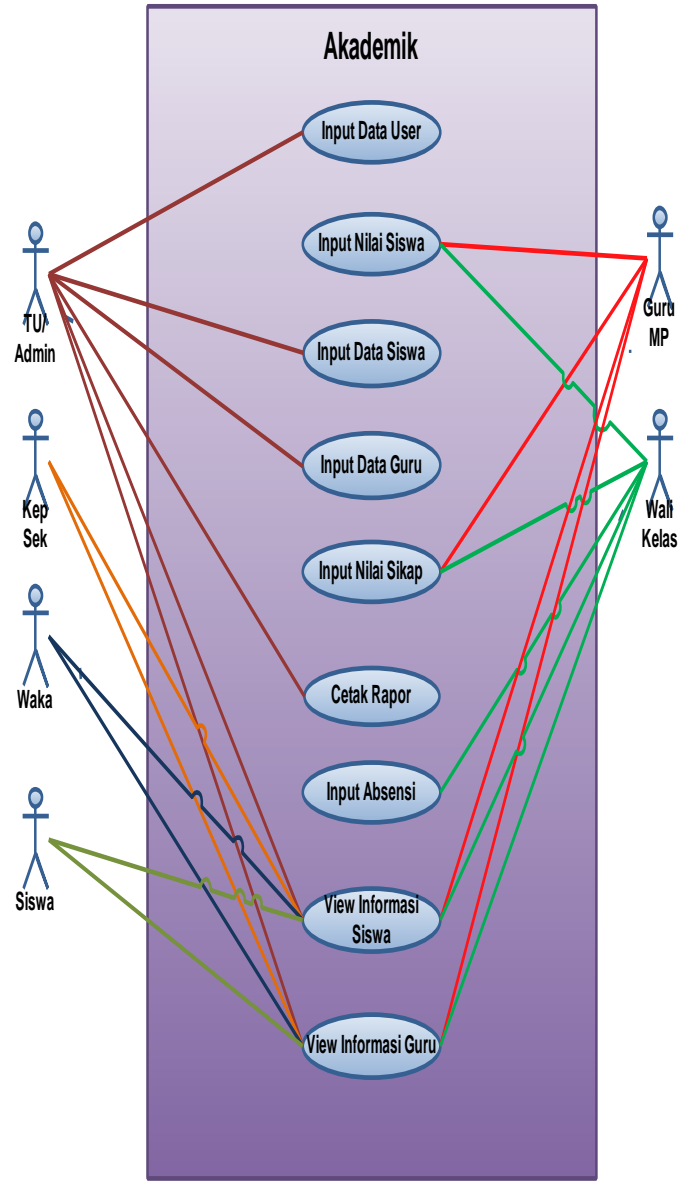

Gambar 6

\section{Use Case Diagram}

Berikut ini penjelasan untuk masingmasing use case yang ada pada Use Case Diagram seperti pada gambar 6.

a. Input Data User

Bagian ini merupakan proses penginputan data user yang memakai sistem informasi akademik SMK Isen Mulang Palangka Raya.

b. Input Data Siswa

Proses ini memang merupakan tugas dan tanggung jawab TU. Setiap penerimaan siswa baru, data siswa dicatat dalam sebuah file excel.

c. Input Data Guru

Proses pada bagian ini juga seperti input data siswa, yaitu merupakan tanggung jawab TU.

d. Input Nilai Siswa

Input nilai siswa wajib dilakukan oleh guru Mata Pelajaran (Guru MP).

e. Input Nilai Sikap

Input nilai sikap merupakan bagian dari tugas dan tanggung jawab guru mata pelajaran.

f. Cetak Rapor

Pencetakan Rapor dilakukan oleh TU. Selama ini TU musti mengolah nilai dari berbagai sumber untuk menghasilkan format rapor yang sesuai.

g. Input Absensi

Bagian penginputan absensi siswa hanya dapat dilakukan oleh wali kelas untuk kelas yang bersangkutan.

h. View Informasi Siswa 
Proses ini merupakan bagian untuk menampilkan data siswa. Proses ini dapat dilakukan oleh semua user sistem informasi akademik SMK Isen Mulang Palangka Raya.

i. View Informasi Guru

Seperti halnya informasi siswa, informasi guru ini juga dapat dilakukan oleh semua user sistem informasi akademik SMK Isen Mulang Palangka Raya.

\section{Kolom Network Description}

Kolom berikut berisikan model jaringan komputer yang digunakan dalam sistem informasi akademik SMK Isen Mulang Palangka Raya. Berikut ini merupakan model topologi jaringan sederhana bagian akademik SMK Isen Mulang Palangka Raya.

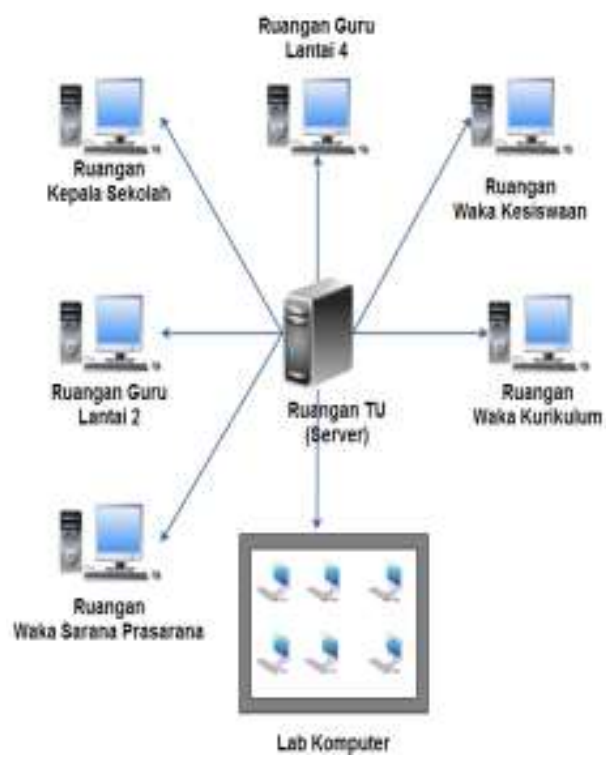

Gambar 7

Topologi Jaringan Sederhana
Dalam penerapannya, ruangan TU akan dijadikan server utama yang menyimpan data dan informasi yang dibutuhkan. Sistem informasi akademik SMK Isen Mulang Palangka Raya dapat diakses dari ruangan kepala sekolah, ruangan guru, ruangan waka kesiswaan, ruangan waka kurikulum, dan lab komputer.

\section{Technology Model (Builder's View)}

Baris ini berisikan model teknologi yang akan digunakan dalam perancangan sistem informasi akademik SMK Isen Mulang Palangka Raya.

\section{Data Description}

Pada bagian data description, dijelaskan mengenai bagaimana sistem informasi akademik berinteraksi dengan user. Dalam hal ini, berupa suatu rancangan GUI dengan menggunakan software GUI Design Studio. Berikut ini adalah gambar struktur menu sistem akademik SMK Isen Mulang Palangka Raya.

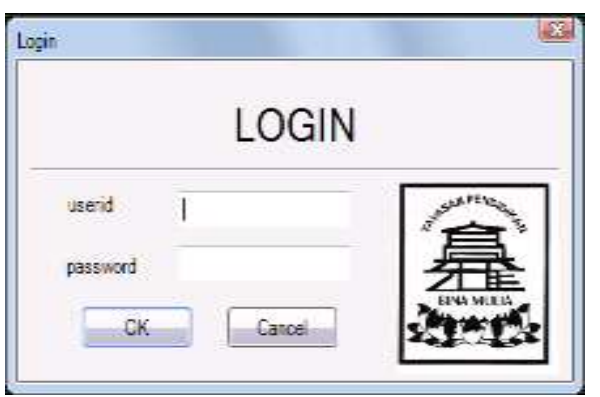

Gambar 9

Form Login 


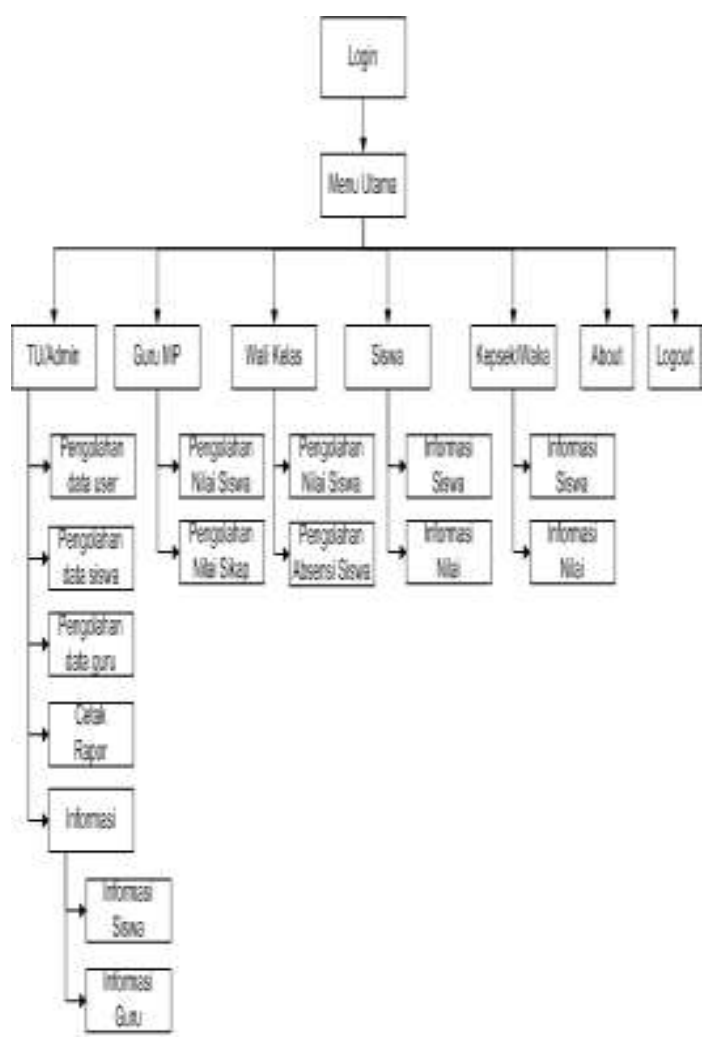

Gambar 8

Struktur Menu Sistem Informasi

Akademik

Form yang perlu dibuat dalam rancangan sistem informasi akademik adalah form login, form menu utama, form pengolahan data user, form pengolahan data siswa, form pengolahan data nilai, form cetak rapor, form informasi siswa, form informasi guru, form pengolahan nilai siswa, form pengolahan nilai sikap, form pengolahan absensi siswa, form informasi nilai, form about, dan form logout.

\section{Process Description}

Pada bagian process description ini akan digambarkan masing-masing form dan penjelasannya. Berikutnya akan digambarkan masing-masing form beserta penjelasannya.

Pada saat pertama dijalankan, sistem informasi akademik SMK Isen Mulang Palangka Raya akan menampilkan form login seperti pada gambar 9.

Pada form ini, user diminta untuk mengisikan userid dan password. Apabila user tidak memasukkan dengan benar userid dan passwordnya, maka akan tampil pesan kesalahan..

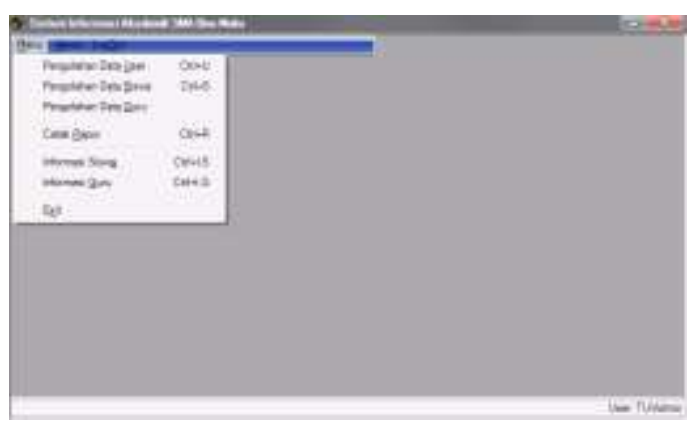

\section{Gambar 10}

Form Menu Utama untuk TU/Admin Gambar 10 merupakan menu untuk user yang login sebagai TU/Admin. S

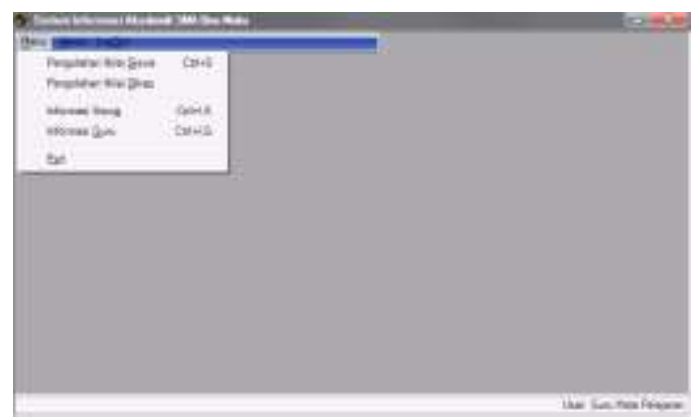

Gambar 11

Form Menu Utama Untuk Guru 
Gambar 11 merupakan menu untuk user yang login sebagai guru mata pelajaran.

Berikut ini adalah contoh tampilan menu utama untuk siswa.

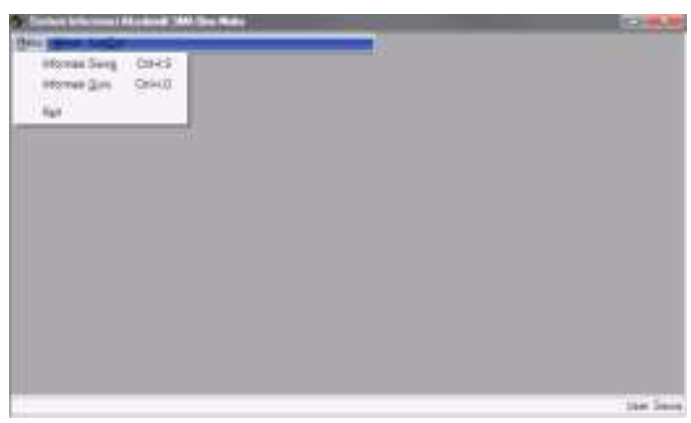

Gambar 12

Form Menu Utama Untuk Siswa

Gambar 12 merupakan menu untuk user yang login sebagai siswa. Seorang siswa hanya dapat menampilkan informasi data siswa, dan menampilkan informasi data guru.

Form pengolahan data user dapat dilihat pada gambar 13 .

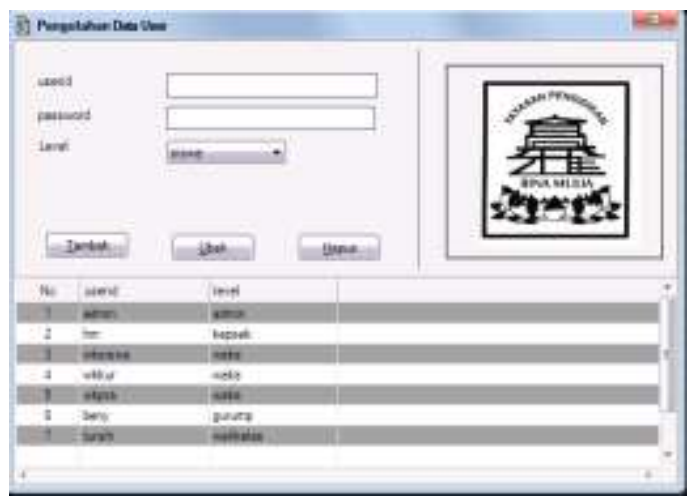

Gambar 13

Form Pengolahan Data User

Form pengolahan data user ini hanya dapat diakses oleh admin. Form ini berguna untuk menambah, mengubah, atau menghapus user.
Berikut merupakan contoh form pengolahan data siswa, yaitu form yang digunakan untuk menambah, mengubah, atau menghapus data siswa.

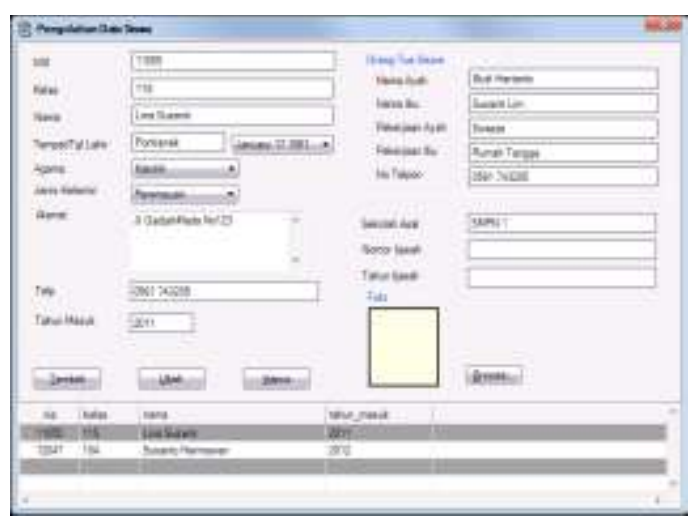

Gambar 14

Form Pengolahan Data Siswa

Pada form ini, bagian NIS, yaitu nomor induk siswa haruslah unik. Apabila NIS yang dimasukkan ternyata sudah ada dalam database, maka program akan memunculkan pesan kesalahan pada saat menekan tombol

Berikutnya adalah contoh perancangan tampilan untuk form pengolahan data guru. Hanya admin yang dapat mengakses menu ini. Contoh tampilan form dapat dilihat pada gambar 15.

Pada form ini, data guru diisikan pada semua field. Nomor NIP (Nomor Induk Pegawai) adalah unik, sehingga apabila NIP yang diisikan sudah ada di database, maka program akan memunculkan dialog pesan kesalahan. 


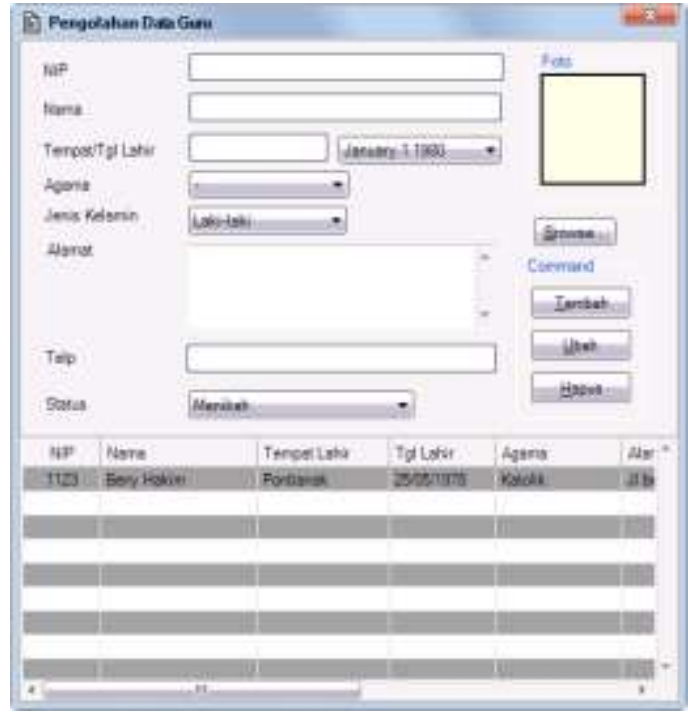

Gambar 15

Form Pengolahan Data Guru

Berikutnya adalah contoh perancangan tampilan untuk form Cetak Rapor.

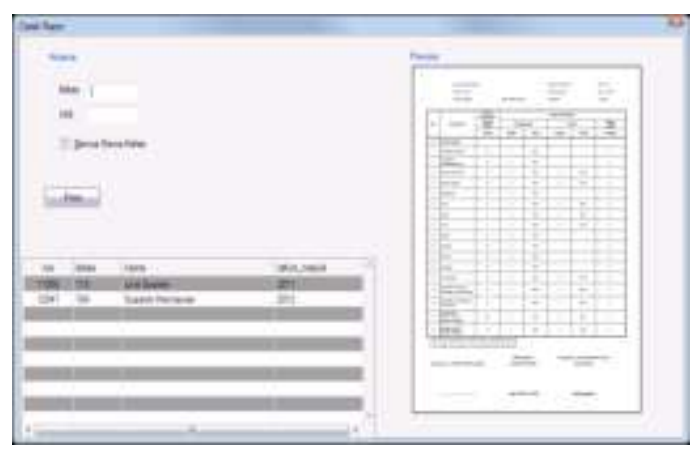

Gambar 16

Form Cetak Rapor

Cetak rapor dapat dilakukan perkelas, ataupun hanya mencetak rapor untuk siswa tertentu. Apabila checkbox "Semua Siswa Kelas" dicentang, maka sistem akan mencetak rapor semua siswa yang aktif pada tahun ajaran aktif.

Berikut ini merupakan contoh kerangka rapor SMK Isen Mulang
Palangka Raya, yang terdiri dari 3 halaman, yang diambil dari rapor untuk siswa kelas XII IPS.

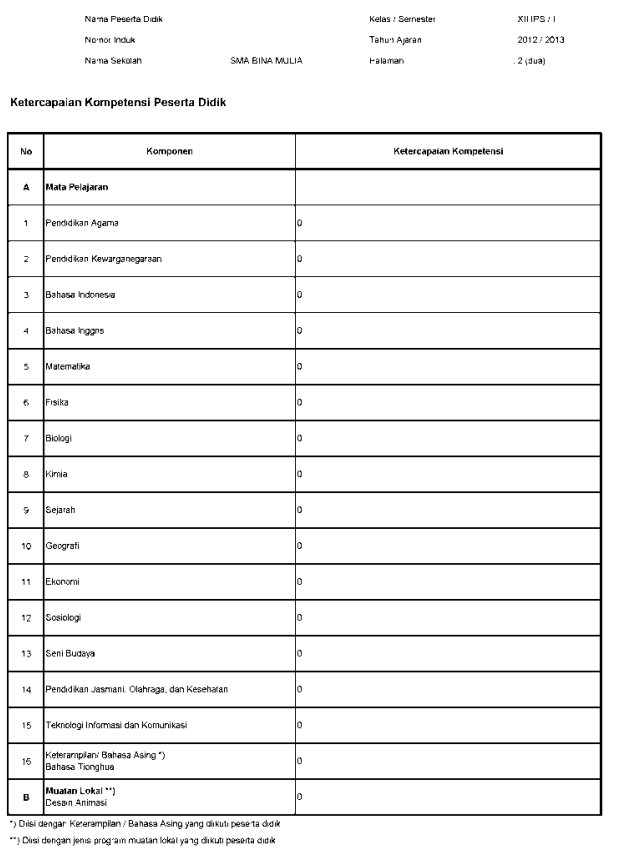

Gambar 17

Kerangka Rapor Halaman Kedua
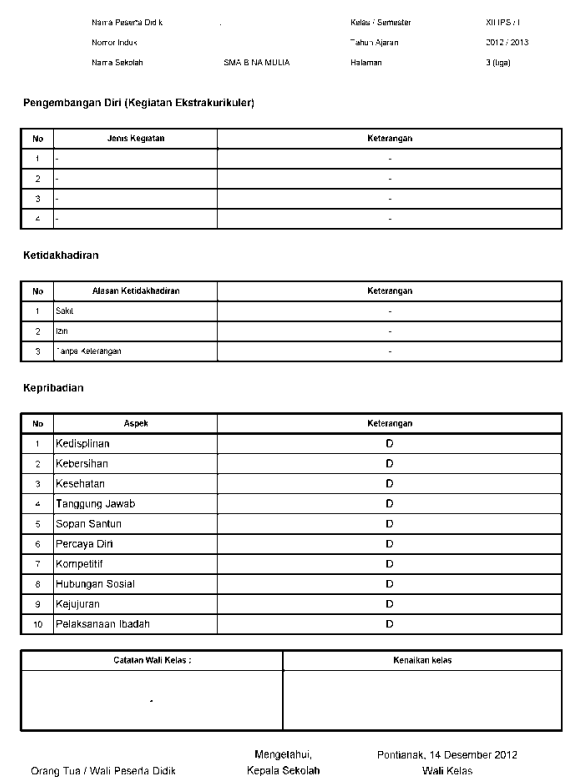

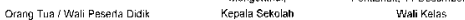

Gambar 18 Kerangka Rapor Halaman Ketiga 
Admin juga dapat melihat informasi siswa dan informasi guru.

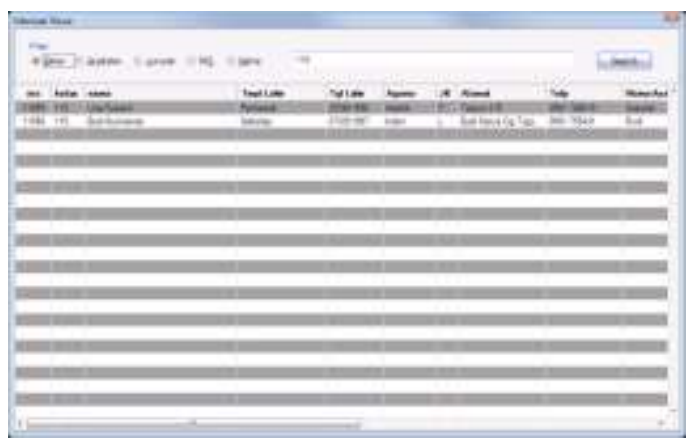

Gambar 19

Form Informasi Siswa

User dapat melakukan filter terhadap informasi siswa. Radio button digunakan untuk memilih kriteria filter yang diinginkan.

Berikut ini merupakan form informasi guru. Form ini dapat diakses oleh semua user tanpa membedakan level. Jadi setiap entitas dapat melihat data guru.

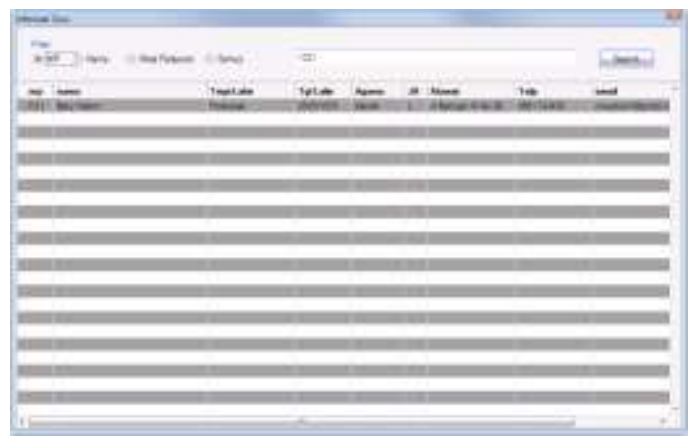

Gambar 20

Form Informasi Guru

User dapat melakukan filter data guru untuk kategori berdasarkan NIP, Nama, atau Mata pelajaran.

Network Description
Pada baris Technology Model kolom Network Description ini, dijelaskan mengenai pemilihan arsitektur jaringan yang akan digunakan dalam sistem informasi akademik SMK Isen Mulang Palangka Raya. Berikut ini adalah gambar arsitektur jaringannya.

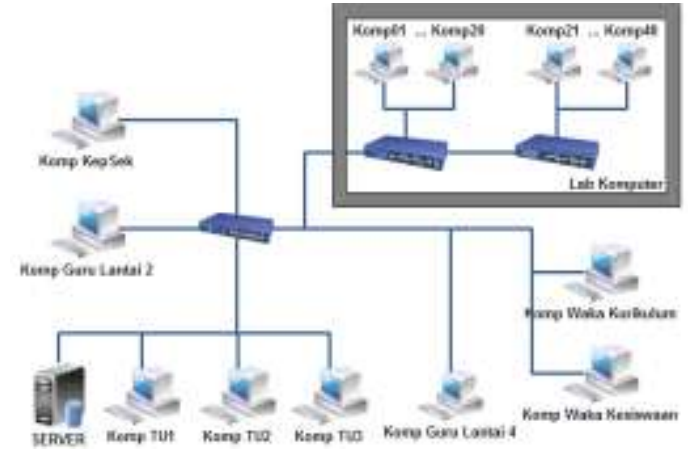

Gambar 21

Arsitektur Jaringan Komputer

Dari gambar arsitektur di atas, terlihat bahwa arsitektur jaringan komputer sistem informasi akademik yang digunakan adalah berjenis topologi star.

\section{Detailed Description (Out-of-Context}

View)

Bagian ini menjelaskan mengenai rancangan database yang digunakan dalam sistem informasi akademik SMK Isen Mulang Palangka Raya.

\section{Data Description}

Bagian ini memuat entitasentitas dan kunci attribut dari database yang digunakan dalam sistem informasi akademik SMK Isen Mulang Palangka 
Raya. Berikut ini merupakan diagram ER dari database sistem informasi akademik.

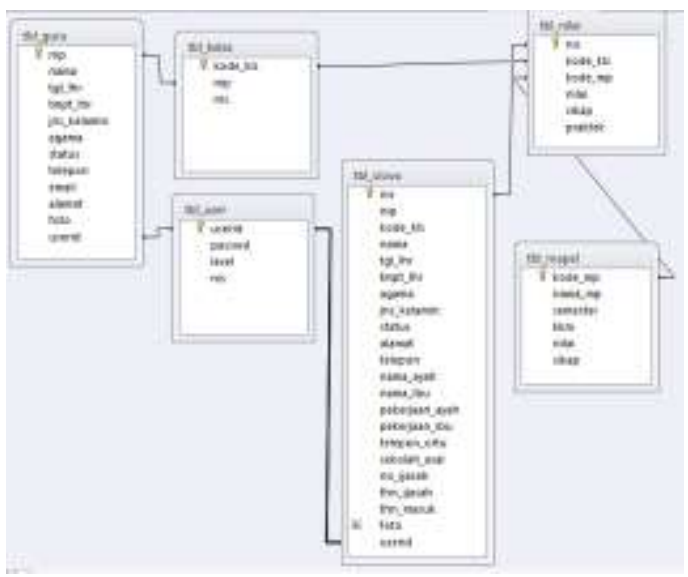

Gambar 22

Diagram E-R Database SIA

\section{Process Description}

Pada bagian data description, dijelaskan mengenai struktur tabel dari masing-masing tabel sesuai dengan yang telah dibicarakan di bagian data description.

Berikut ini merupakan struktur tabel dalam sistem informasi akademik SMK Isen Mulang Palangka Raya.

Tabel 1

Struktur Tabel User

\begin{tabular}{|l|l|c|l|}
\hline $\begin{array}{l}\text { Nama } \\
\text { Field }\end{array}$ & $\begin{array}{l}\text { Tipe } \\
\text { Data }\end{array}$ & Ukuran & Keterangan \\
\hline userid & Text & 30 & id user \\
\hline passwd & Text & 30 & $\begin{array}{l}\text { password } \\
\text { user }\end{array}$ \\
\hline level & Number & 1 & $\begin{array}{l}\text { Tingkat hak } \\
\text { akses }\end{array}$ \\
\hline
\end{tabular}

Tabel user digunakan untuk menyimpan data pengguna sistem informasi akademik. Tingkatan akses dapat dilihat pada tabel berikut ini.

Tabel 2

Tabel Hak Akses

\begin{tabular}{|c|l|}
\hline Level & Keterangan \\
\hline 1 & Hak akses administrator. \\
\hline 2 & Hak akses kepsek. \\
\hline 3 & Hak akses waka \\
\hline 4 & s walikelas \\
\hline 5 & Hak akses guru mata pelajaran \\
\hline 6 & Hak akses siswa \\
\hline
\end{tabular}

Berikutnya merupakan struktur tabel Siswa. Tabel ini digunakan untuk menyimpan data siswa.

Tabel 3

Tabel Siswa

\begin{tabular}{|l|l|l|l|}
\hline $\begin{array}{l}\text { Nama } \\
\text { Field }\end{array}$ & $\begin{array}{l}\text { Tipe } \\
\text { Data }\end{array}$ & Ukuran & Keterangan \\
\hline nis & Text & 10 & $\begin{array}{l}\text { nomor } \\
\text { induk siswa }\end{array}$ \\
\hline kode_kls & Text & 4 & $\begin{array}{l}\text { kode kelas } \\
\text { siswa }\end{array}$ \\
\hline nama & Text & 30 & nama siswa \\
\hline
\end{tabular}




\begin{tabular}{|c|c|c|c|}
\hline tgl_lhr & $\begin{array}{l}\text { Date/Tim } \\
\text { e }\end{array}$ & - & $\begin{array}{l}\text { tanggal lahir } \\
\text { siswa }\end{array}$ \\
\hline tmpt_lhr & Text & $\begin{array}{l}2 \\
5\end{array}$ & $\begin{array}{l}\text { tempat lahir } \\
\text { siswa }\end{array}$ \\
\hline agama & Text & $\begin{array}{l}1 \\
5\end{array}$ & Agama Siswa \\
\hline jns_kelamin & Text & 1 & $\begin{array}{l}\text { Jenis kelamin } \\
(\mathrm{L} / \mathrm{P})\end{array}$ \\
\hline status & Text & $\begin{array}{l}1 \\
5\end{array}$ & $\begin{array}{l}\text { kandung/buk } \\
\text { an }\end{array}$ \\
\hline alamat & Text & $\begin{array}{l}5 \\
0\end{array}$ & alamat siswa \\
\hline telepon & Text & $\begin{array}{l}1 \\
2\end{array}$ & $\begin{array}{l}\text { nomor } \\
\text { telepon siswa }\end{array}$ \\
\hline nama_ayah & Text & $\begin{array}{l}3 \\
0\end{array}$ & $\begin{array}{l}\text { nama ayah } \\
\text { siswa }\end{array}$ \\
\hline nama_ibu & Text & $\begin{array}{l}3 \\
0\end{array}$ & $\begin{array}{l}\text { nama ibu } \\
\text { siswa }\end{array}$ \\
\hline $\begin{array}{l}\text { pekerjaan_ay } \\
\text { ah }\end{array}$ & Text & $\begin{array}{l}2 \\
0\end{array}$ & $\begin{array}{l}\text { pekerjaan } \\
\text { ayah siswa }\end{array}$ \\
\hline $\begin{array}{l}\text { pekerjaan_ib } \\
\mathrm{u}\end{array}$ & Text & $\begin{array}{l}2 \\
0\end{array}$ & $\begin{array}{l}\text { pekerjaan ibu } \\
\text { siswa }\end{array}$ \\
\hline telepon_ortu & Text & $\begin{array}{l}1 \\
2\end{array}$ & $\begin{array}{l}\text { nomor } \\
\text { telepon orang } \\
\text { tua siswa }\end{array}$ \\
\hline sekolah_asal & Text & $\begin{array}{l}3 \\
0\end{array}$ & $\begin{array}{l}\text { nama sekolah } \\
\text { asal siswa }\end{array}$ \\
\hline no_ijasah & Text & $\begin{array}{l}2 \\
0\end{array}$ & $\begin{array}{l}\text { nomor ijasah } \\
\text { terakhir } \\
\text { siswa }\end{array}$ \\
\hline thn_ijasah & Number & - & $\begin{array}{l}\text { tahun ijasah } \\
\text { siswa }\end{array}$ \\
\hline thn_masuk & Number & - & $\begin{array}{l}\text { tahun masuk } \\
\text { siswa }\end{array}$ \\
\hline foto & $\begin{array}{l}\text { Attachme } \\
\text { nt }\end{array}$ & - & $\begin{array}{l}\text { pas foto } \\
\text { siswa }\end{array}$ \\
\hline userid & Text & 3 & id user siswa \\
\hline
\end{tabular}

Selanjutnya merupakan tabel mata pelajaran yang digunakan untuk menyimpan nama mata pelajaran beserta nilai kriteria ketuntasan minimum (KKM) untuk tiap-tiap mata pelajaran.

Tabel 4

Tabel Mata Pelajaran

\begin{tabular}{|l|l|l|l|}
\hline $\begin{array}{l}\text { Nama } \\
\text { Field }\end{array}$ & $\begin{array}{l}\text { Tipe } \\
\text { Data }\end{array}$ & Ukuran & Keterangan \\
\hline kode_mp & Text & 3 & $\begin{array}{l}\text { kode mata } \\
\text { pelajaran }\end{array}$ \\
\hline nama_mp & Text & 30 & $\begin{array}{l}\text { nama mata } \\
\text { pelajaran }\end{array}$ \\
\hline semester & Number & - & $\begin{array}{l}1=\text { ganjil, } \\
=\text { genap }\end{array}$ \\
\hline kkm & Number & - & nilai KKM \\
\hline
\end{tabular}


Berikut ini merupakan struktur tabel nilai yang digunakan untuk menyimpan nilai tiap siswa per mata pelajaran, nilai sikap per mata pelajaran, dan nilai praktek untuk mata pelajaran yang memerlukan nilai praktek.

Tabel 5

Tabel Nilai

\begin{tabular}{|l|l|l|l|}
\hline $\begin{array}{l}\text { Nama } \\
\text { Field }\end{array}$ & $\begin{array}{l}\text { Tipe } \\
\text { Data }\end{array}$ & Ukuran & Keterangan \\
\hline nis & Text & 10 & $\begin{array}{l}\text { No Induk } \\
\text { Siswa }\end{array}$ \\
\hline kode_kls & Text & 4 & $\begin{array}{l}\text { Kode Kelas } \\
\text { Siswa }\end{array}$ \\
\hline kode_mp & Text & 3 & $\begin{array}{l}\text { Kode Mata } \\
\text { Pelajaran }\end{array}$ \\
\hline nilai & number & - & $\begin{array}{l}\text { Nilai Per } \\
\text { Mata } \\
\text { Pelajaran }\end{array}$ \\
\hline Sikap & number & - & nilai sikap \\
\hline Praktek & number & - & nilai praktek \\
\hline
\end{tabular}

\begin{tabular}{|c|c|c|c|}
\hline & & & Lahir Guru \\
\hline $\begin{array}{l}\text { jns_kela } \\
\text { min }\end{array}$ & Text & 1 & $\begin{array}{l}\text { Jenis } \\
\text { Kelamin } \\
(\mathrm{L} / \mathrm{P})\end{array}$ \\
\hline agama & Text & 15 & Agama Guru \\
\hline status & Text & 15 & $\begin{array}{l}\text { Menikah/Bel } \\
\text { um Menikah }\end{array}$ \\
\hline Telepon & Text & 12 & $\begin{array}{l}\text { Nomor } \\
\text { telepon Guru }\end{array}$ \\
\hline email & Text & 30 & $\begin{array}{l}\text { Alamat } \\
\text { Email Guru }\end{array}$ \\
\hline alamat & Text & 50 & Alamat Guru \\
\hline foto & $\begin{array}{l}\text { Attachme } \\
\text { nt }\end{array}$ & - & $\begin{array}{l}\text { Pas Foto } \\
\text { Guru }\end{array}$ \\
\hline userid & Text & 30 & id user guru \\
\hline
\end{tabular}

Selanjutnya merupakan struktur tabel guru, digunakan untuk menyimpan data pribadi guru.

Tabel 6

\section{Tabel Guru}

\begin{tabular}{|l|l|l|l|}
\hline $\begin{array}{l}\text { Nama } \\
\text { Field }\end{array}$ & $\begin{array}{l}\text { Tipe } \\
\text { Data }\end{array}$ & $\begin{array}{l}\text { Ukura } \\
\mathbf{n}\end{array}$ & Keterangan \\
\hline nip & Text & 20 & $\begin{array}{l}\text { Nomor Induk } \\
\text { Pegawai }\end{array}$ \\
\hline nama & Text & 30 & Nama Guru \\
\hline tgl_lhr & $\begin{array}{l}\text { Date/Tim } \\
\text { e }\end{array}$ & - & $\begin{array}{l}\text { Tanggal } \\
\text { Lahir Guru }\end{array}$ \\
\hline tmpt_lhr & Text & 25 & Tempat \\
\hline
\end{tabular}




\section{Network Description}

Bagian ini memuat bagaimana database tersebar dalam tiap lokasi yang berhubungan dengan proses akademik di SMK Isen Mulang Palangka Raya. Dalam perancangan ini, program Akademik SMK Isen Mulang Palangka Raya menggunakan sistem database terpusat, yaitu database hanya berada di server utama, yaitu di ruangan TU.

\section{SIMPULAN}

Untuk membuat suatu perencanaan Sistem Informasi Akademik di SMK Isen Mulang Palangka Raya dengan menggunakan Zachman Framework, langkah-langkahnya adalah:

a. Melakukan pengumpulan data, misalnya data guru, data siswa, data nilai, dan lain-laindengan menggunakan teknik observasi, partisipasi, dan studi dokumentasi.

b. Mengetahui gambaran keadaan, masalah, dan kebutuhan dengan cara menganalisis data yang sudah dikumpulkan sebelumnya.

c. Berdasarkan hasil analisis, kemudian membuat perencanaan sistem informasi akademik dengan menggunakan Zachman Framework yang meliputi: Mengidentifikasi halhal (entitas) yang penting dalam sistem informasi akademik untuk sel pada baris Scope Description. Untuk baris Model of the Business (Owner's View), dijabarkan business rule dalam model diagram E-R untuk kolom Data Description. Untuk baris Model of Information System (Designer's View), pada kolom Data Descriptiondilakukan penjabaran model konseptual dari sistem yang akan dibangundengan menggunakan diagram E-R yang dilengkapi dengan atribut. Untuk baris Technology Model (Builder's View), dilakukan penjabaran model aktual dari sistem yang akan dibangun, yaitu rancangan user interface (GUI).Pada baris Detailed Description (Out-of-Context View), dilakukan penjabaran mengenai database yang akan digunakan dalam sistem informasi akademik SMK Isen Mulang Palangka Raya.

\section{DAFTAR PUSTAKA}

Adhinugraha, K. M. (2007).

Pemanfaatan Framework

Zachman dalam Pembangunan

Sistem Informasi. Dalam A. T. dkk (Penyunt.), Prosiding Konferensi Nasional Sistem Informasi 2007. Bandung: Informatika.

Cassidy, A. (2006). A Practical Guide to Information Systems Strategic Planning. Auerbach Publication. 
Daryatmo, B. (2007). Perancangan Cetak Biru Teknologi Informasi. Algoritma Jurnal Ilmiah STMIK MDP Palembang.

Djam'an, S., \& Aan, K. (2011). Metodologi Penelitian Kualitatif. Bandung: Alfabeta.

Etta, M. S., \& Sopiah. (2010). Metodologi Penelitian. Andi Offset.

Jack, V. W., Hofman, A., Stahlecker, M., Hartman, H., \& Waage, M. (2010). The Integrated Architecture Framework Explained. Springer.

Laudon, K. C., \& Laudon, J. P. (2012). Management Information Systems. Prentice Hall.

Minoli, D. (2008). Enterprise Architecture A to Z: frameworks, business process modeling, SOA, and infrastructure technology. CRC Press.

Nana, S. S. (2005). Metode Penelitian Pendidikan. PT Remaja Rosdakarya.

Radiant, V. I., \& Ria, H. M. (2008).

Analisis Pemodelan Sistem Informasi Telkom Speedy Menggunakan Zachman Framework. Jurnal Sistem Informasi Vol. 3 No. 2 September, 154-178.
Ritson, N. (2008). Strategic Management. Neil Ritson \& Ventus Publishing ApS.

Shelly, G. B., \& Rosenblatt, H. J. (2012). Systems Analysis and Design, Ninth Edition. USA: Cengage Learning.

Surendro, K. (2007). Pemanfaatan Enterprise Architecture Planning Untuk Perencanaan Strategis Sistem Informasi. Jurnal Informatika Vol. 8 No. $1 \mathrm{M} \mathrm{ei,1-}$ 9.

Valacich, J. S., George, J. F., \& Hoffer, J. A. (2012). Essentials of Systems Analysis and Design. USA: Pearson Education Inc 